\title{
RANCANGAN SISTEM PENJUALAN BERBASIS WEB DENGAN METODE WATERFALL PADA CV. KARSAL CIPTA MANDIRI BOGOR
}

\author{
Holilah Romlah $^{1}$, Dini Setyorini ${ }^{2}$, Rosmita $^{3}$, Elpa Hermawan ${ }^{4}$ \\ ${ }^{1,2,3}$ Fakultas Teknik dan Informatika, ${ }^{4}$ Fakultas Komunikasi dan Bahasa, Universitas Bina Sarana \\ Informatika (UBSI) \\ Jl. Kramat Raya no. 98 Kwitang, Kecamatan Senen, Jakarta Pusat 10450 \\ e-mail : $\underline{\text { holydila@gmail.com }}{ }^{1}, \underline{\text { dini.die@ bsi.ac.id }}$, $\underline{\text { rosmita.rmt@bsi.ac.id }}$, elpa.ehn@bsi.ac.id
}

\begin{abstract}
At the present time the website has grown very rapidly in the last few years. This can be seen from the number of people from the community to companies from various fields that need and depend on the use of websites to support daily activities, including sales. Sales is part of an information system that plays a very important role in the company's operations. CV. Karsal Cipta Mandiri is a local company engaged in the sale of office stationery. CV. Karsal Cipta Mandiri already has a very broad marketing, but in the process of selling CV. Karsal Cipta Mandiri still uses manual marketing, namely the customer must come to the store first, look at the design of the goods and then process the order written in a book. This often results in data loss and recording errors. So, we need a web-based sales design to assist the company in data processing and report generation. Web-based sales are also useful as a media for product sales promotion, which can facilitate the sales transaction process. The author uses the method of collecting data with observations and interviews with waterfall method as a method at information system development. Database design using ERD and LRS, work process using UML. By having a sales website, the sellers will look more professional and trustworthy. Besides that, the security in managing the business will also be more guaranteed than selling conventionally because it is efficient and can be accessed anywhere.
\end{abstract}

Keywords—system, sales, waterfall

\section{ABSTRAK}

Pada masa sekarang website berkembang sangat pesat dalam beberapa tahun terakhir. Perkembangan ini dapat kita temukan dari banyaknya masyarakat umum hingga perusahaan dari berbagai sektor menggunakan dan bergantung pada website yang sangat mendukung aktivitas perusahaan di berbagai bidang salah satunya adalah penjualan. Penjualan adalah unsur dari dari sistem informasi yang sangat berperan dalam operasional perusahaan. CV. Karsal Cipta Mandiri merupakan perusahaan lokal yang bergerak dibidang penjualan alat tulis kantor. CV. Karsal Cipta Mandiri sudah memiliki pemasaran yang sangat luas, namun dalam proses penjualan CV. Karsal Cipta Mandiri masih menggunakan pemasaran yang masih manual, yaitu customer harus datang ke toko terlebih dahulu, melihat-lihat design barang kemudian proses pemesanan yang ditulis dengan buku. Hal tersebut sering menimbulkan kehilangan data dan kesalahan pencatatan. Oleh sebab itu perlu dibuat sistem berbasis komputer untuk mengatasi 
masalah dalam penjualan sampai dengan laporan penjualan selesai. Penjualan berbasis web juga berguna sebagai media promosi penjualan produk, yang dapat memudahkan dalam proses transaksi penjualan. Metode yang digunakan yaitu pengumpulan data dengan pengamatan dan wawancara bagian terkait dan menggunakan metode waterfall untuk pengembangan software. Perancangan database menggunakan ERD dan LRS, kemudian untuk mengetahui proses alur kerja sistem penulis menggunakan berbagai macam diagram Unified Modeling Language (UML). Dengan memiliki web penjualan, penjualan dapat dilakukan lebih profesional dan terpercaya. Dalam mengelola bisnis perlu dilihat juga data akan lebih terjamin secara komputerisasi dari pada menjual secara konvensional karena adanya otomatisasi yang efisien dan memudahkan mengakses secara online.

Kata Kunci_ - sistem, penjualan, waterfall

\section{Pendahuluan}

Perkembangan teknologi komputer saat ini dapat kita lihat semakin pesat dan banyak diminati oleh masyarakat hingga organisasi perusahaan. Dalam kegiatan sehari-hari kita dapat melihat setiap manusia menggunakan teknologi komputer tak terkecuali dalam pekerjaan mereka di perusahaan. Sistem informasi dan teknologi informasi dalam hal ini berfungsi sebagai pendukung untuk mengambil keputusan yang tepat berdasarkan informasi yang tersedia. Sistem informasi juga bermanfaat dan berguna sebagai sarana untuk membantu dalam proses berlangsungnya bisnis [1].Terlebih dimasa pandemi Covid-19 saat ini banyaknya penggunaan komputer semakin meningkat dikarenakan banyak diminati oleh kalangan masyarakat hingga perusahaan dari berbagai bidang yang membutuhkan dan tergantung pada pemanfaatan komputer guna mendukung kegiatan sehari-hari. Perusahaan harus memiliki kemampuan menjual produk untuk mendapatkan keuntungan. Menurut Basu Swastha DH tujuan umum penjualan dalam perusahaan yaitu [2]: mencapai volume penjualan, mendapatkan laba tertentu, menunjang pertumbuhan perusahaan.

Dalam dunia usaha seperti perdagangan erat kaitannya dengan transaksi penjualan, yang kegiatan utamanya selalu berhubungan dengan pengolahan data, maka sangat dibutuhkan komputer untuk penyediaan informasi yang cepat dan mempermudah mengorganisasikan data-data yang masuk maupun transaksi yang tercatat. Dengan bantuan sebuah komputer, kegiatan penyimpanan data maupun transaksi tidak lagi dilakukan diatas kertas yang menghabiskan cukup banyak tempat penyimpanan serta bisa mengurangi kehilangan data. Penggunaan teknologi yang tepat, termasuk teknologi dibidang 
informasi akan menghasilkan informasi yang cepat, tepat dan efisien [3].

Penjualan dapat berupa produk atau jasa yang ditawarkan kepada masyarakat, yang prosesnya memberikan sesuatu komoditi kepada pembeli dengan timbal balik berupa harga tertentu. Kebutuhan penjual terpenuhi dengan pembeli dapat membeli secara kredit atau tunai [4]."

"System Development Life Cycle (SDLC) adalah suatu pendekatan yang memiliki tahap atau bertahap untuk melakukan analisa dan membangun suatu rancangan sistem dengan menggunakan siklus yang lebih spesifik terhadap kegiatan pengguna. System Development Life Cycle (SDLC) juga merupakan pusat pengembangan sistem informasi yang efisien [5]."

CV. Karsal Cipta Mandiri menyediakan alat tulis kantor (ATK) berbentuk toko yang dapat dikunjungi umum, berlokasi di Bojong Gede Bogor. Pada CV. Karsal Cipta Mandiri penjualannya menggunakan sistem manual baik dalam pencatatan dan pembuatan laporan sehingga sering terjadi kehilangan data, selain itu dengan sistem manual dan penjualan yang semakin banyak maka untuk merekap data penjualan akan mengalami kesulitan dan pembuatan laporan menjadi kurang maksimal. Manager atau pemilik toko mengalami kesulitan dalam mengambil keputusan karena menerima laporan yang terlambat dan kurang akurat. Laporan terlambat karena harus mengumpulkan data secara manual dari faktur yang ada. Penjualan berbasis web sebagai media sarana promosi penjualan produk, yang dapat memudahkan dalam mengelola proses transaksi penjualan. Dengan adanya sistem penjualan, laporan yang dibuat lebih terpercaya dan cepat apabila pemilik toko ingin mengambil keputusan. Tingkat keamanan lebih terjaga dan para pekerja lebih dipercaya dibandingkan dengan mencatat di buku, sehingga pekerjaan dapat lebih efektif dan efisien dalam mengelola produk.

Berdasarkan pemaparan tersebut dan hasil observasi yang dilakukan di CV. Karsal Cipta Mandiri Bogor, diperlukan sebuah rancangan sistem informasi penjualan berbasis web untuk membantu pihak penjual dalam melakukan proses pemesanan produk dan memperluas pasang pasar, juga mempermudah dalam proses pengolahan data dan pembuatan laporan penjualan. Dengan begitu teori berikut dapat membantu pembuatan perancangan sistem informasi :

Sebelum membuat perancangan usulan ada baiknya kita mengenal sistem yang merupakan gabungan unsur-unsur dengan tujuan yang sama untuk mencapai tujuan.Tetapi unsur-unsur yang sama tidak 
selalu dimiliki oleh sistem. Tujuan yang sama merupakan hal yang terpenting dalam suatu sistem. Masukan atau input, proses, keluaran atau output, batasan, mekanisme pengendalian dan umpan balik serta lingkungan merupakan unsur yang ada dalam sistem. Tohari mengemukakan Kumpulan atau himpunan dari unsur tersebut merupakan variabel-variabel yang saling terkait, saling berinteraksi, dan saling tergantung satu sama lain dalam mencapai tujuannya [6].

Dapat juga dilihat kombinasi dari prosedur kerja, informasi, teknologi dan orang yang diorganisasikan untuk mencapai tujuan dalam sebuah organisasi [7].

\section{a. Karakteristik Sistem}

Sistem memiliki karakteristik diantaranya yaitu [8]:

a. Komponen Sistem (Components) Bagian atau elemen yang dapat bewujud benda atau manusia, berbentuk atau abstrak, dan disebut subsistem.

\section{b. Penghubung antar bagian (Interface)}

Penghubung berfungsi menyambung atau menjembatani satu elemen dengan elemen yang lain, sehingga interaksi atau komunikasi antar bagian dapat terjalin.

\section{c. Batasan (Boundary)}

Sistem yang satu dengan yang lain dapat dibedakan dengan adanya batasan.

\section{d. Lingkungan (Environment)}

Lingkungan berada di luar sistem dan dapat mempengaruhi jalannya sistem.

$$
\text { e. Masukan (Input) }
$$

Masukan atau input adalah hal yang siap diolah dalam sistem.

f. Mekanisme pengolahan (Processing)

Kegaiatan mengubah input atau masukan menjadi output atau keluaran.

g. Keluaran (Output)

Hasil atau produk yang dikeluarkan dari proses pengolahan.

\section{h. Tujuan (Goal/Objective)}

Hasil akhir yang diharapkan dari adanya sistem dapat berupa jangka panjang ataupun jangka pendek.

i. Sensor dan kendali (Sensor and Control)

Dalam proses pengolahan pada suatu sistem perlu adanya pengawasan atau pemantauan sehingga sistem berjalan sesuai dengan yang diharapkan, mendapatkan hasil akhir sesuai harapan .

\section{j. Umpan-Balik (Feedback)}

Umpan balik merupakan manfaat yang didapatkan dari sistem informasi tersebut.

\section{b. Sistem Informasi}

Unsur perangkat lunak seperti (software), perangkat keras (hardware), manusia (brainware), prosedur (procedure), basisdata (database), dan juga jaringan komputer (communication network) harus 
ada semua dalam sebuah sistem informasi. Apabila salah satu dari hal di atas tidak ada maka sistem informasi tidak dapat berfungsi dengan baik.

c. Website

Untuk menjelajahi, menyajikan, maupun mengambil konten yang ada di berbagai sumber informasi pada jaringan internet diperlukan website atau WWW. Pengertian dari web browser juga sering disebut dengan suatu perangkat lunak dengan fungsi yang dimilikinya sebagai penerima, pengakses, penyaji berbagai informasi di internet [9].

\section{Metode Penelitian}

Pengembangan sistem informasi yang akan diterapkan pada penjualan di CV. Karsal Cipta Mandiri Bogor menggunakan metode waterfall atau Sekuensial Linear atau alur hidup klasik (Classic Life Cycle) yang merupakan alur hidup sebuah sistem dimulai dari anaisis, design, perancangan sampai dengan pemeliharaan.

Metode waterfall adalah model yang paling cocok untuk pengembangan perangkat lunak karena sangat sederhana dan terarah dan tidak mengalami perubahan.

Adapun tahapan-tahapan metode waterfall, sebagai berikut : [10]
1. Tahap Analisis Kebutuhan Perangkat Lunak

Pada tahapan ini penyusun telah melakukan studi kasus atau observasi pada CV. Karsal Cipta Mandiri Bogor untuk mengetahui prosedur penjualan hingga pembuatan laporan yang berjalan di tempat tersebut, juga menganalisa apasaja yang dibutuhkan oleh sistem.

2. Desain

Desain perangkat lunak yang digunakan oleh penulis berdasarkan kebutuhan dari pengguna yaitu desain pembuatan perangkat lunak termasuk diagram Unified Modeling Language (UML), gambar Entity Relationship Diagram (ERD), serta diagram Logical Record Structure (LRS), representasi antarmuka atau pembuatan rancangan tampilan prototype sistem penjualan menggunakan software Adobe XD hingga dapat menggambarkan tampilan program yang akan dibuat.

3. Implementasi dan Pengujian

Tahap implementasi adalah tahap yang menjelaskan mengenai sistem yang telah dirancang dan menjabarkan rancangan pembuatan sistem yang sesuai dengan analisis. Setelah tahap implementasi maka selanjutnya melakukan tahap pengujian terhadap sistem yang telah di rancang, pada tahap ini kita dapat melihat bahwa apa yang 
ingin kita capai ada pada sistem tersebut sesuai dengan tujuan awal, dengan menggunakan metode blackbox testing, sistem akan diuji secara fungsional, tanpa mengetahui struktur internal kode.

4. Pendukung (support) atau pemeliharaan (maintenance)

Pada saat sistem telah selesai diuji, tahapan selanjutnya yaitu proses pendukung dengan melakukan kegiatan pelatihan dan sosialisasi penggunaan sistem usulan pada CV. Karsal Cipta Mandiri Bogor. Selanjutnya, tahap pemeliharaan yang dilakukan setelah perangkat lunak digunakan. Pada proses ini yaitu dengan mengoreksi apabila terdapat kesalahan pada perangkat lunak yang melakukan penyesuaian atau perubahan sesuai dengan lingkungan baru.

\section{Hasil Dan PEMBahasan}

\section{Prosedur Sistem Berjalan}

Sistem yang sedang berjalan dalam proses penjualan alat tulis kantor pada $\mathrm{CV}$. Karsal Cipta Mandiri, sebagai berikut:

a) Proses Pemesanan

Pelanggan melakukan pemesanan barang dengan datang langsung ke $\mathrm{CV}$. Karsal Cipta Mandiri atau dapat pula melakukan pemesanan melalui telepon, atau SMS.

Setelah melakukan pemesanan, staf penjual akan mengecek ketersediaan barang. Jika barang tersedia, maka staf penjual akan menyiapkan barang pesanan dan membuatkan 2 rangkap faktur (Faktur A, Faktur B) yang berisi barang pesanan dan rincian jumlah harga yang harus dibayar oleh pelanggan.

Jika barang tidak tersedia, staf penjual akan menginfokan stok barang tersebut habis kepada staf gudang, sehingga staf gudang dapat mencatatnya pada daftar barang dan dapat segera dibeli.

b) Proses Pembayaran

Setelah membuat faktur, selanjutnya staf penjualan akan memberikan barang pesanan beserta 1 rangkap faktur A kepada pelanggan untuk proses pembayaran. Pelanggan melakukan transaksi pembayaran atas barang yang telah dibeli tersebut kepada staf penjual secara tunai. Staf penjual yang telah menerima pembayaran akan mengarsipkan 1 faktur B dan membuat bukti pembayaran berupa kwitansi.

c) Pembuatan Laporan

Setelah mengarsipkan faktur, staf penjual akan membuat laporan penjualan. Kemudian laporan tersebut diberikan kepada pemilik toko.

\section{Perancangan Sistem Usulan}

Pada tahapan ini kebutuhan sistem dilakukan untuk membentuk dan menjabarkan kebutuhan pengguna menjadi 
design system yang kemudian akan dibuat menjadi program aplikasi. Penulis melihat kebutuhan dari sisi Admin dan Pemilik Toko yang selalu menggunakan software tersebut, kebutuhan ini meliputi input data, mengelola data barang, dan mengelola penjualan. Analisa kebutuhan dalam perancangan sistem penjualan berbasis web pada CV. Karsal Cipta Mandiri Bogor, sebagai berikut:

\section{a) Kebutuhan Pengguna}

Kebutuhan pengguna dalam perancangan sistem penjualan terbagi atas dua kebutuhan diantaranya kebutuhan admin, dan kebutuhan Pemilik Toko. Kebutuhan admin dan pemilik toko memiliki informasi yang berbeda baik dari kebutuhan dan karakteristiknya, sebagai berikut :

1) Kebutuhan Admin

a) Admin yang pertama kali dilakukan adalah memasukan username dan password pada saat login.

b) Admin dapat mengelola data data barang dan data kategori, menambahkan, mengedit serta menghapus data.

c) Admin mengelola data customer, mengedit atau menghapus data.

d) Admin mengelola transaksi penjualan.
2) Kebutuhan Pemilik Toko

a) Pemilik Toko dapat mengakses halaman Pemilik Toko memasukan username dan password pada saat login.

b) Pemilik Toko dapat mengelola data admin, mengubah, menambahkan atau menghapus data admin.

c) Pemilik Toko dapat melihat laporan penjualan.

3) Kebutuhan Sistem

Kebutuhan sistem dalam perancangan sistem penjualan berbasis web ini harus berjalan dengan baik dalam memenuhi kebutuhan pengguna. Kebutuhan sistem yang dibutuhkan diantaranya sebagai berikut :

a) Kebutuhan Admin

1) Sistem akan menampilkan halaman login.

2) Sistem akan menampilkan halaman khusus admin.

3) Sistem pada halaman admin dapat menampilkan data customer, dan melakukan aksi seperti mengedit atau menghapus.

4) Sistem dapat menampilkan data barang dan kategori, dan melakukan aksi menambah 
data, mengedit atau menghapus data barang.

5) Sistem dapat menampilkan data transaksi penjualan

b) Kebutuhan Pemilik Toko

1) Sistem dapat menampilkan halaman login Pemilik Toko.

2) Sistem dapat menampilkan halaman khusus Pemilik Toko.

3) Sistem pada halaman Pemilik Toko dapat menampilkan admin.

4) Sistem pada halaman Pemilik Toko dapat

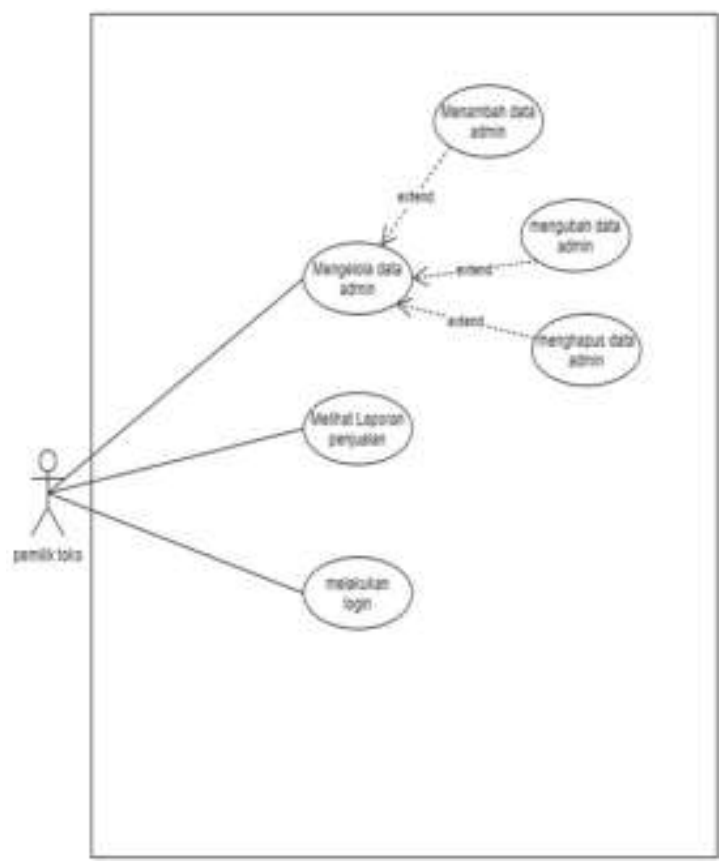

Gambar 2. Gambar Use Case Pemilik Toko menampilkan laporan penjualan.

Berikut gambar dari perancangan sistem usulan yang sudah diuraikan di atas:
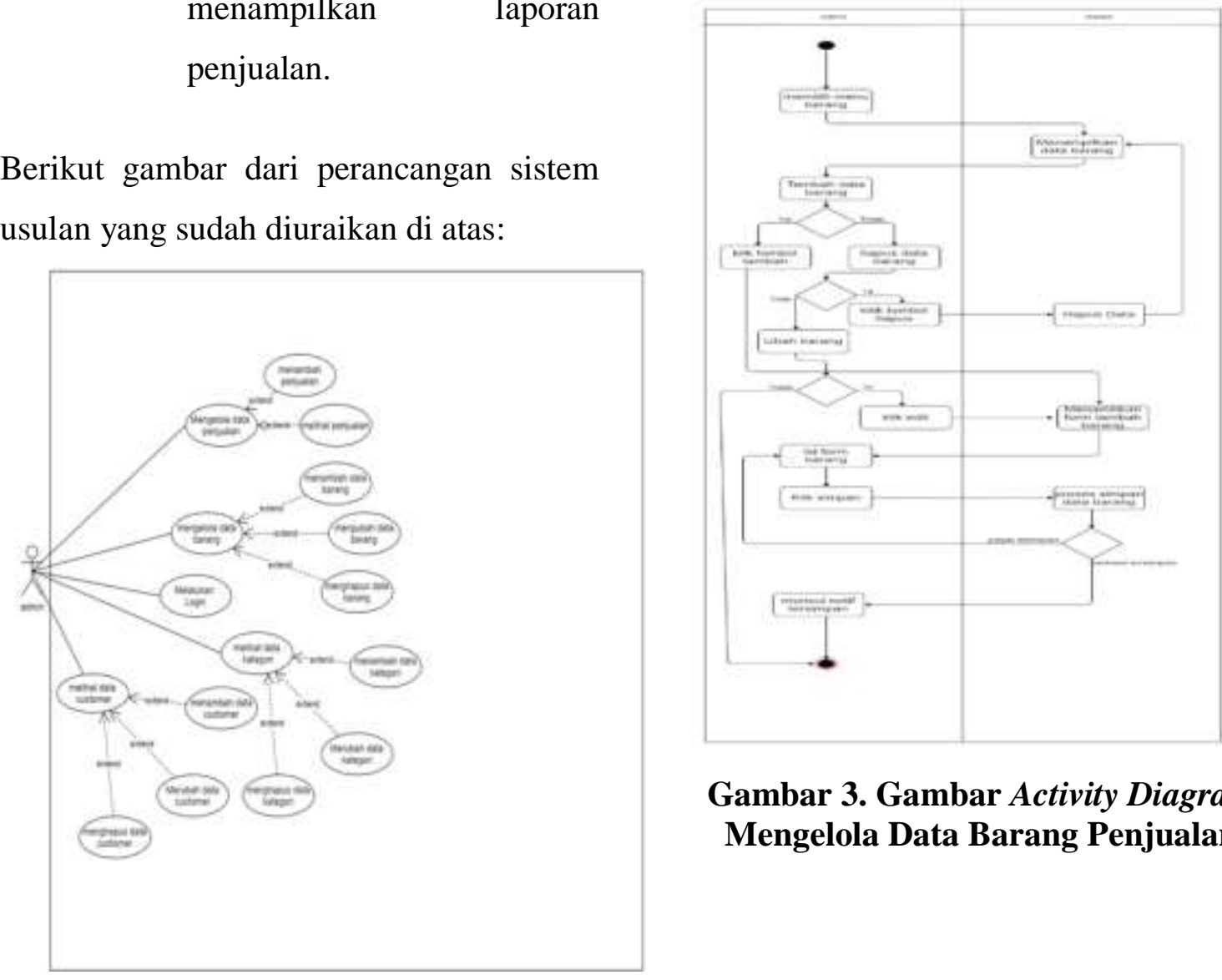

Gambar 3. Gambar Activity Diagram Mengelola Data Barang Penjualan

Gambar 1. Gambar Use Case Admin 


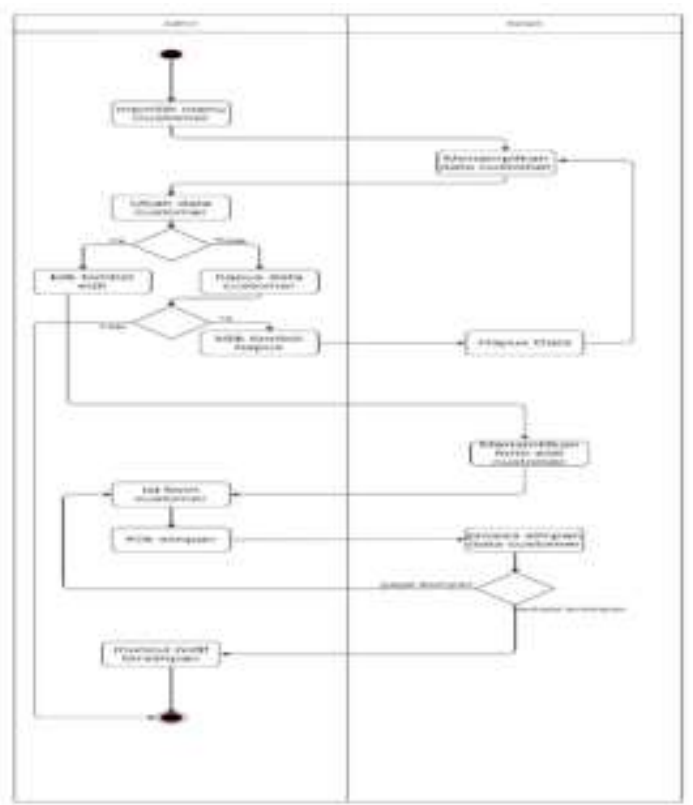

Gambar 4. Gambar Activity Diagram Mengelola Data Konsumen

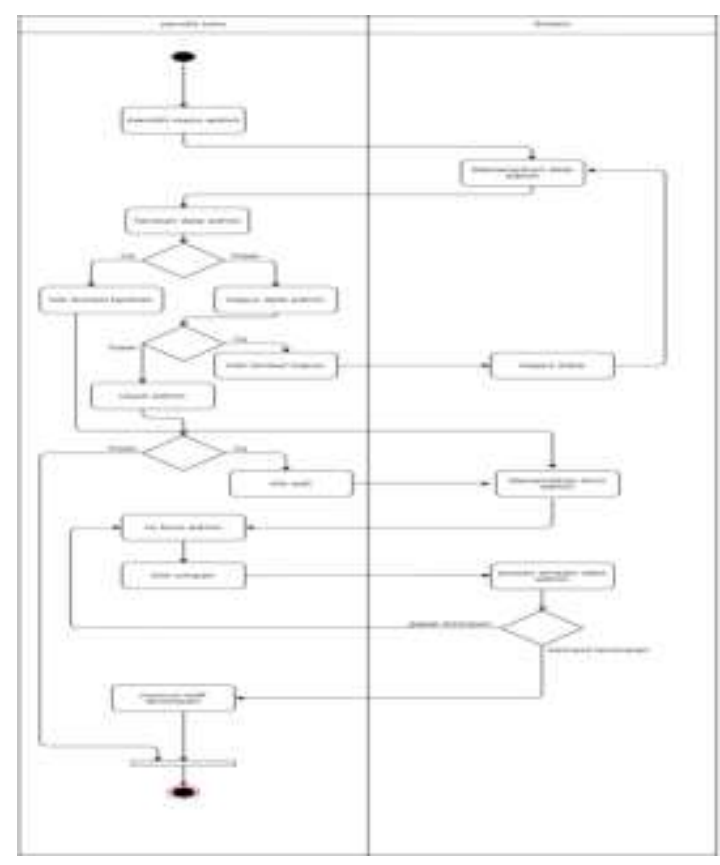

Gambar 5. Gambar Activity Diagram Mengelola Data Admin

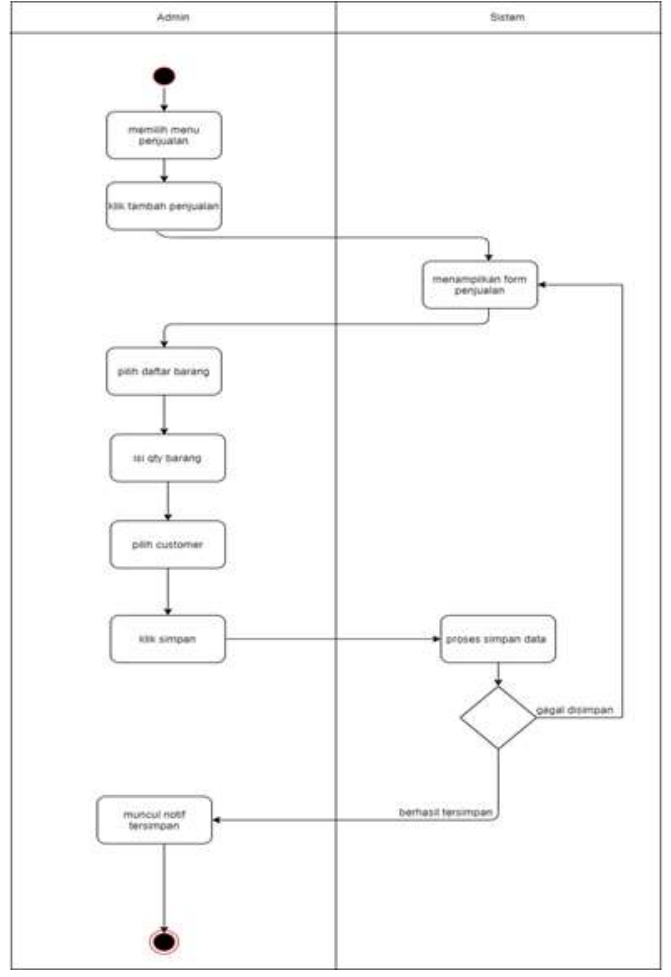

Gambar 6. Gambar Activity Diagram Mengelola Data Penjualan

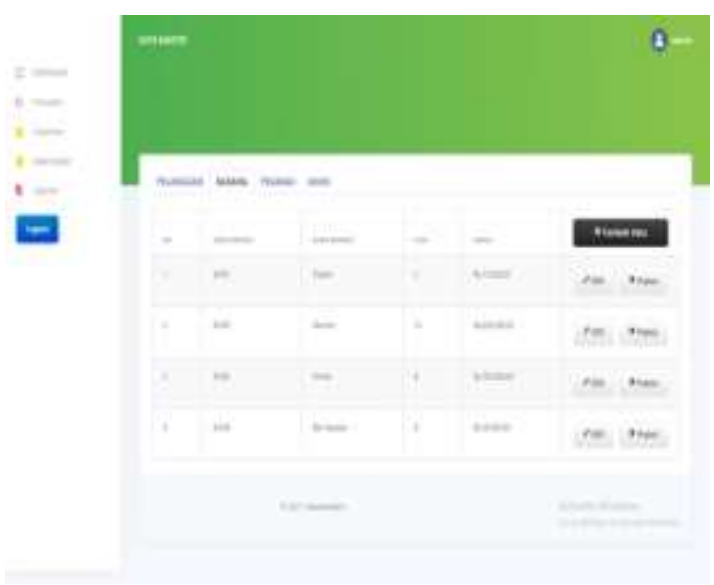

Gambar 7. Prototype atau Mock Up Tampil Data Barang 


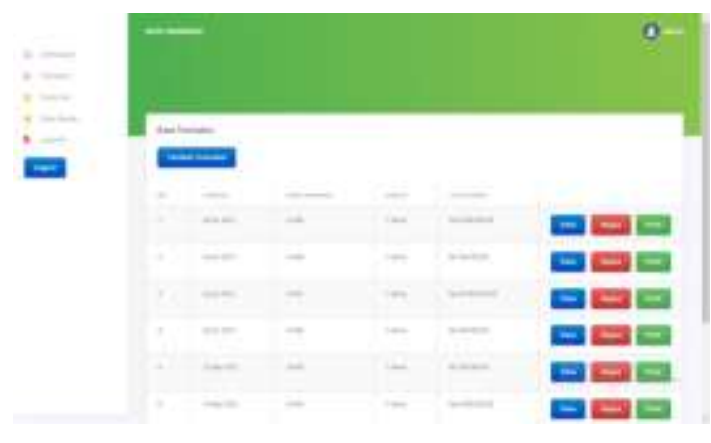

Gambar 8. Prototype atau Mock Up Tampil Data Penjualan

\section{Pengujian Antar Muka}

I. Kasus uji: Login, langkah uji:

a. Akses alamat website,

b. Memasukan username dan password,

c. Tampil dashboard,

d. Hasil yang diharapkan: Dashoard menu utama perusahaan tersimpan untuk kemudian login,

e. Hasil actual: Username dan password dapat digunakan login,

f. Keterangan: Berhasil.

II. Kasus uji: Kelola data barang, langkah uji:

a. User memilih menu kelola data barang,

b. Aktifitas tambah, edit dan hapus data barang,

c. Hasil yang diharapkan: Data barang akan berhasil dikelola,

d. Hasil actual: Data barang berhasil dikelola, e. Keterangan: Berhasil.

III. Kasus uji: Kelola data pegawai, langkah uji:

a. User memilih menu kelola data pegawai,

b. Aktifitas tambah, edit dan hapus data pegawai,

c. Hasil yang diharapkan: Data pegawai akan berhasil dikelola,

d. Hasil actual: Data pegawai berhasil dikelola,

e. Keterangan: Berhasil.

IV. Kasus uji: Kelola data customer, langkah uji:

a. User memilih menu kelola data customer,

b. Aktifitas tambah, edit dan hapus data customer,

c. Hasil yang diharapkan: Data customer akan berhasil dikelola,

d. Hasil actual: Data customer berhasil dikelola,

e. keterangan: Berhasil.

V. Kasus uji: Kelola data penjualan, langkah uji:

a. User memilih menu kelola data penjualan,

b. Aktifitas menambah data penjualan,

c. Hasil yang diharapkan: Data penjualan akan berhasil dikelola, 

d. Hasil actual: Data penjualan berhasil dikelola,
e. Keterangan: Berhasil.

\section{SimpUlan}

Berdasarkan penelitian yang telah dilakukan pada CV. Karsal Cipta Mandiri Bogor mengenai perancangan sistem informasi penjualan maka dapa kesimpulan yang didapat sebagai berikut:

1. CV. Karsal Cipta Mandiri pada saat ini masih menggunakan sistem cara konvensional dengan memesan barang langsung ke toko dan pencatatan masih menggunakan kertas yang ditulis tangan. Dengan adanya penjualan berbasis web dapat meningkatkan keamanan dalam mengelola bisnis, sehingga penjual akan terlihat lebih profesional dan terpercaya. Dan penjualan berbasis web juga sebagai sarana promosi penjualan produk.

2. Perancangan sistem penjualan yang penulis analisa di CV. Karsal Cipta Mandiri Bogor pada sistem tersebut adalah design perancangan database menggunakan ERD dan LRS, kemudian untuk mengetahui proses alur kerja sistem penulis menggunakan berbagai macam diagram Unified Modeling Language (UML), dengan metode waterfall dan juga perancangan tampilan antarmuka prototype.

\section{DAFTAR PUSTAKA}

[1]Nurudin, M., Jayanti, W., Saputro, R. D., Saputra, M. P., \& Yulianti, Y., 2019, Pengujian Black Box pada Aplikasi Penjualan Berbasis Web Menggunakan Teknik Boundary Value Analysis, Jurnal Informatika Universitas Pamulang, vol 4(4), hal 143,https://doi.org/10.32493/informatik a.v4i4.3841

[2]Sasangka, I., \& Rusmayadi, R., 2018, Pengaruh Kualitas Pelayanan Terhadap Volume Penjualan, Jurnal Ilmiah Manajemen Ekonomi Dan Akutansi, vol 2(1).

[3]Ardyanto, E., Prasetyo, C. P., \& Safa, M., 2019, Rancang Bangun Sistem Informasi Penjualan Alat Tulis Kantor ( ATK ) Berbasis Desktop Pada Badan Usaha Milik Desa Bersama ( BUMDESMA ) Kandangan Mandiri Abstrak A . PENDAHULUAN Sebuah perusahaan sebagai suatu organisasi yang memiliki kecenderungan orientas, Jurnal TECNOSCIENZA, vol 4(1) hal 113-122.

[4]Zaliluddin, D., \& Rohmat, R., 2018, Perancangan Sistem Informasi Penjualan Berbasis Web (Studi Kasus Pada Newbiestore), Infotech Journal, 
vol 4(1) hal 236615.

[5]Dwanoko, Y. S., 2016, Implementasi

Software Development Life Cycle (Sdlc)

Dalam Penerapan Pembangunan

Aplikasi Perangkat. Jurnal Teknologi Informasi, vol 7(2) hal 83-94, Retrieved from http://ejurnal.stimata.ac.id/index.php/TI /article/view/219

[6]Mariana, A. R., Husnia, S., Stmik, D., Sarana, B., Stmik, M., \& Sarana, B., 2017, Rancangan Sistem Informasi Petty Cash Bimbingan Belajar dan Kursus, vol 7(1).

[7]Ningrum, T. H., Umar, M. K. G., \&

Subhan, 2020, Sistem Informasi Penerimaan Berkas Badan Usaha Jasa Konstruksi pada Lembaga Pengembangan Jasa Konstruksi (LPJK) Provinsi Maluku Utara, Jurnal Ilmiah ILKOMINFO - Ilmu Komputer \& Informatika, vol 3(1), hal43-51. https://doi.org/10.47324/ilkominfo.v3i1 .93

[8]Masripah, S., Nurhidayati, Syamsiah, N. O., \& Haryani., 2019, Analisa Perancangan Sistem Informasi Akuntansi, Graha Ilmu, Jakarta.

[9]Januarisman, E., \& Ghufron, A., 2016, Pengembangan Media Pembelajaran Berbasis Web Mata Pelajaran Ilmu Pengetahuan Alam Untuk Siswa Kelas Vii. Jurnal Inovasi Teknologi
Pendidikan, vol 3(2), hal 166. https://doi.org/10.21831/jitp.v3i2.8019

[10]Sasmito, G. W., 2017, Penerapan Metode Waterfall Pada Desain Sistem Informasi Geografis Industri Kabupaten Tegal, Jurnal Informatika: Jurnal Pengembangan IT, vol 2(1) hal 6-12.

https://doi.org/10.30591/JPIT.V2I1.435 